Pamiętnik Literacki 2018, 4, s. 235-250

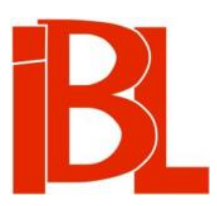

\title{
Czy Jakub Wujek znał angielski? "Nowy Testament" z 1593 roku i angielskie źródło jego paratekstu
}

Tadeusz Rubik 
Pamiętnik Literacki CIX, 2018, z. 4, PL ISSN 0031-0514

DOI: $10.18318 / \mathrm{pl} .2018 .4 .15$

TADEUSZ RUBIK Uniwersytet Warszawski

\section{CZY JAKUB WUJEK ZNAE ANGIELSKI? „NOWY TESTAMENT” Z 1593 ROKU I ANGIELSKIE ŹRÓDŁO JEGO PARATEKSTU*}

Tzw. Biblia Wujka ${ }^{1}$ jako przekład Pisma Świętego przyjęta była w Kościele katolickim w Polsce od 1599 roku do ukazania się Biblii Tysiąclecia w 1965 roku. Bez wątpienia należy więc do tekstów najważniejszych dla kultury polskiej. Tłumaczenie to otacza obszerna literatura przedmiotu, do której zaliczają się przede wszystkim prace historyczne i językoznawcze, powstające od początku XX wieku. Najistotniejsze ustalenia przypadły na lata pięćdziesiąte i sześćdziesiąte, nowsze badania w przeważającej mierze zależne są od ówczesnych wyników prac Jana Poplatka, Władysława Smereki i Kazimierza Drzymały, opartych na analizie (części) istniejącego i dostępnego materiału archiwalnego ${ }^{2}$ oraz (jak w wypadku rozpraw np. Konrada Gąsiorowskiego) na analizie przekładu Jakuba Wujka ${ }^{3}$.

Wiedzy, którą dysponujemy, nie można nazwać kompletną; wymaga ona aktualizacji. Okolicznością wręcz obligującą do podjęcia takiej pracy jest dostrzeżenie problematyki źródeł komentarzy apologetycznych i polemicznych, znajdujących się w tzw. Biblii Wujka. Pomysł przygotowania nowego polskiego tłumaczenia Biblii zrodził się w latach osiemdziesiątych XVI wieku w Towarzystwie Jezusowym. Takie działanie sami jezuici otwarcie określali jako interwencyjne, wymuszone przez serię coraz doskonalszych wydań protestanckich: lepszych przekładów, korygują-

* Praca naukowa finansowana ze środków budżetowych na naukę w latach 2018-2022 jako projekt badawczy w ramach programu Diamentowy Grant.

1 Mówiąc o tzw. Biblii Wujka, nie zamierzam wchodzić w spór na temat tego, czy jest to faktycznie Biblia Wujka czy Biblia niby-Wujkowa (zob. np. J. G ołą b, O ttumaczeniu „Nowego Testamentu” przez ks. Jakuba Wujka. Warszawa 1906, s. 21), skoro „pośmiertni korektorzy przekładu Wujka przez liczne poprawki i niewolnicze trzymanie się łacińskiej Wulgaty stworzyli właściwie nową redakcję Biblii Wujkowej” (K. G ą s i o row s k i, Dwa psatterze ks. Wujka. „Ruch Biblijny i Liturgiczny" 1959, nr 3, s. 255). Chciałbym jedynie zasygnalizować problem niemożliwości - przynajmniej na tym etapie badań - stwierdzenia, co tak naprawdę od Wujka pochodzi. Zob. D. A. Frick, Polish Sacred Philology in the Reformation and the Counter-Reformation. Chapters in the History of the Controversies (1551-1632). Berkeley - Los Angeles - London 1989, s. 133-235.

2 K. Drzymała: Ks. Jakub Wujek z Wagrowca 1541-1957. „Ruch Biblijny i Liturgiczny” 1950, nr 1/2; Wpływ ks. Stanisława Grodzickiego T. J. na ttumaczenie „Biblii” ks. Jakuba Wujka T. J. „Polonia Sacra" 1951, z. 1. - J. P o pl a t e k, Obecny stan badań nad życiem Jakuba Wujka T. J. i program dalszej pracy. Jw., 1950, z. 1/2. - W. S m e r e ka, wstęp w: „Nowy Testament” w przekładzie ks. dr Jakuba Wujka T. J. z roku 1593. Wstępem i uwagami poprz. W. S m e r e ka. Kraków 1966. Gą s i o row ski, op. cit., passim. 
cych „błędy” ${ }^{4}$ poprzednich, a także poprawianych i rozwijanych środków edytorskich i komentatorskich. Dlatego również dodanie katolickiego aparatu egzegetycznego w postaci - przede wszystkim - obszernych „nauk i przestróg” w NT1593, „annotacyj” w PS1594 czy „wykładów miejsc trudniejszych” w wydaniu B15995 było reakcją na komentarze zamieszczane $\mathrm{w}$ przekładach różnowierczych, zwłaszcza w Biblii brzeskiej6.

Dodane do NT1593 roku objaśnienia są w dużej mierze zależne od tekstu „annotations" $\mathrm{z}$ The New Testament of Iesus Christ, Translated Faithfully into English [...], wydanego przez angielskich rekuzantów ze środowiska Douai-Reims w 1582 roku$^{7}$. Zwrócił na to uwagę David A. Frick w rozprawie Polish Sacred Philology 8 , rozwinął zaś te zagadnienia w artykule Anglo-Polonica. The Rheims New Testament of 1582 and the Making of the Polish Catholic Bible $\mathrm{z} 1991$ roku$^{9}$, który w Polsce pozostawał nieznany przez 25 lat.

W niniejszym artykule podejmuje zagadnienie źródeł paratekstu NT1593 (edycji kontrolowanej przez Wujka ${ }^{10}$ ), omawiam także perspektywy badań, jakie otwierają się w momencie dostrzeżenia tej relacji intertekstualnej. Komentarze do PS1594, wydania również kontrolowanego przez tłumacza, oraz kompletnej edycji B1599, wytłoczonej już po śmierci Wujka, charakteryzują się inną problematyką, jedynie sygnalizowaną w końcowej części rozprawy.

\section{Paratekst NT1593 i stan badań nad jego źródłami}

Wujek w Przedmowie do czytelnika dokładnie przedstawił aparat krytyczny, jaki zamieszczono w wydaniu ${ }^{11}$. Przy tekście NT1593 znajduja się więc: 1) noty marginalne, zawierające odmiany tekstu w źródłach łacińskich i w wersji greckiej, odsyłacze do innych ustępów Pisma Świętego, informacje o miejscu danej perykopy

4 Tu i dalej słowo „błędy” umieszczam w cudzysłowie, aby zaznaczyć, że chodzi nie tylko o faktyczne usterki translatologiczne, ale raczej o decyzje przekładowe wynikające z przesłanek konfesyjnych i $z$ takich pozycji krytykowane.

5 Pisząc o poszczególnych dziełach translatorskich J. W ujka, posługuję się następującymi skrótami: NT1593 = Nowy Testament Pana naszego Jezusa Chrystusa, znowu z tacińskiego i z greckiego na polskie wiernie a szczyrze przełożony i argumentami abo summariuszami każdych ksiag i rozdziałów i annotacjami po brzegach objaśniony [...]. Kraków 1593; PS1594 = Psatterz Dawidów teraz znowu z łacińskiego, z greckiego i z żydowskiego na polski język z pilnościa przełożony $i$ argumentami i annotacjami objaśniony [...]. Kraków 1594; B1599 = Biblia, to jest Księgi Starego $i$ Nowego Testamentu według łacińskiego przekładu starego $w$ Kościele powszechnym przyjętego na polski język znowu z pilnościa przełożone [...]. Kraków 1599.

6 Zob. J. Wuj ek, Przedmowa do czytelnika. W: „Nowy Testament” $w$ przekładzie ks. dr Jakuba Wujka T. J. z roku 1593, s. LI-LXXI. - M. Ła s z c z [?], Apparatus Sacer, to jest przygotowanie do pożytecznego czytania „Pisma Świętego”. B1599. Zob. Fr i ck, op. cit., s. 133-235.

7 The New Testament of Iesus Christ, Translated Faithfully into English [...]. Transl. M. G r e go ry. Rhemes 1582 (dalej: DRNT).

8 Frick, op. cit., s. 154, przypis 66.

9 D. A. Frick, Anglo-Polonica. The Rheims New Testament of 1582 and the Making of the Polish Catholic Bible. „The Polish Review” 1991, nr 1.

10 Taką edycją był również Nowy Testament Pana naszego Jezusa Chrystusa [...] z 1594 roku (Kraków), „wydanie popularne" przekładu Wujka, pozbawione marginaliów i komentarza.

11 W u j e k, Przedmowa do czytelnika, s. LX-LXXI. 
w porządku roku liturgicznego, argumenty wydobywające główną myśl fragmentu bądź podsumowujące go ${ }^{12}$; oraz: 2) „nauki i przestrogi”, obszerne komentarze następujące po prawie każdym rozdziale. Część z nich uzasadnia konkretne decyzje translatorskie lub na podstawie analizy treści wyjaśnia sens tekstu natchnionego, inne omawiają realia biblijne bądź przedstawiają katolicką egzegezę danych fragmentów, czasem na zasadzie pozytywnego wykładu doktryny, niekiedy zaś wchodząc $\mathrm{w}$ polemikę $\mathrm{z}$ tezami protestantów i korzystając przy tym $\mathrm{z}$ metod teologii kontrowersyjnej ${ }^{13}$. Każdą $z$ ksiąg i każdy $z$ rozdziałów poprzedza summa, a więc streszczenie, w wypadku tych pierwszych nieco dłuższe, w wypadku drugich ograniczające się zazwyczaj do kilku krótkich haseł. Ponadto przed tekstem natchnionym pojawiaja się jeszcze: Summa Nowego Testamentu, Summa Czterech Ewangelii oraz Summa i porzadek historyjej Ewangelijej świętej [...], zestawiona w tabeli synopsa. Wydanie zamykają: Regestr, abo Tablica Epistoł i Ewangelii [...], lista czytań zebranych według porządku roku liturgicznego, i indeks tematyczny - Regestr, abo spisek słów i rzeczy przedniejszych [...].

W Przedmowie do czytelnika z NT1593 Wujek wskazywał również na źródła opisanego przez siebie paratekstu ${ }^{14}$. Była to, w wypadku marginaliów, Wulgata lowańska, z której przeniesiono wiele not zawierających variae lectiones w tekstach łacińskich, co udokumentowała Paulina Nicko-Stępień ${ }^{15}$. „Nauki i przestrogi” zaś:

częścią z samego Pisma św., częścią też z wykładu starych onych Ojców i Doktorów kościelnych, których imiona mało nie wszędy są położone, częścią też i z nowych, a na imię z Bellarmina i z annotacyj Nowego Testamentu angielskiego od katolików w Remsie, we Francyjej roku Pańskiego 1582 wydanego, są zebrane $[\ldots]^{16}$.

Do momentu ukazania się pracy Biblia Polonorum Rajmunda Pietkiewicza, która sygnalizowała problem zapożyczeń z angielskiego Nowego Testamentu, powszechnie - z wyjątkiem Fricka - podzielano założenie, że Wujek samodzielnie przygotował komentarze, tzn. korzystał z tekstów autorów katolickich $z$ różnych czasów i na ich podstawie układał własne objaśnienia ${ }^{17}$. Frick udowodnił, iż część z roku 1593. Studium Mt 16, 13-20. „Odrodzenie i Reformacja w Polsce” 2015. Zob. J. C z e rn i at ow i c z, Niektóre problemy naukowe grecystyki $w$ pracach biblistów polskich XVI i XVII $w$. Teksty greckie a polskie przekłady. Wrocław 1969, s. 79. - J. F r a n k o w s k i, „Psałterz Dawidów” z 1594 roku $w$ przekładzie ks. Jakuba Wujka i jego znaczenie. W zb.: „Psałterz Dawidow” w przekładzie ks. Jakuba Wujka z 1594 roku. Transkrypcja, słowo wstępne, komentarze J. Frankowski. Warszawa 1993, s. 19, przypis 10.

16 W uj e k, Przedmowa do czytelnika, s. LXX.

17 Zob. np. D. Bi eń k ow s k a, Jak Jakub Wujek „Pismo święte” najęzyk polski przekładat. (O warsztacie tłumacza i technice przez niego stosowanej). „Bobolanum” 1998, z. 1. - S o b c zy k o wa, op. cit. Warto na marginesie wspomnieć, że jeszcze w 1906 roku nie musiało to być oczywiste, skoro G ołą b (op. cit., s. 13; podkreśl. T. R.) pisał: „Wykład b r ał Wujek częścią z komentarzy dawnych Ojców i Doktorów kościelnych, a z nowszych z Bellarmina, jako też i z Annotacyi Nowego Testamentu angielskiego, wydanego przez katolików w Reims, we Francyi w r. 1582". W przypisie 5 na tejże stronicy G ołą b nadmieniał: „uwagi i objaśnienia tego Nowego Testamentu były niezmiernie ostre”. 
paratekstu NT1593 zależna jest od DRNT. Jego badania przypomniał Pietkiewicz ${ }^{18}$. W artykule zamieszczonym w „Odrodzeniu i Reformacji w Polsce” z roku 2017 taka proweniencję komentarzy potwierdziła Nicko-Stępień ${ }^{19}$. Wzbogaciła jednocześnie korpus znanych źródeł o Disputationes de controversiis Christianae Fidei Roberta Bellarmina, wskazując na partie objaśnień, stanowiące dość dokładne tłumaczenie tej rozprawy. Innym dziełem, skąd Wujek czerpał inspiracje, była jego autorstwa Postylla katoliczna (1573), z której skopiował fragmenty, wykorzystując raz już opracowany tekst ${ }^{20}$.

Wymienione materiały (oprócz Postylli katolicznej) zostały wspomniane w przedmowie do NT1593. Ich adaptacja w komentarzach nie budzi więc zaskoczenia. Zdumiewa natomiast skala zależności objaśnień w NT1593 - liczne i obszerne ustępy sa przepisane ze źródeł i wyglaadają na ich dosłowne tłumaczenie ${ }^{21}$. Falsyfikuje to twierdzenie o wysokim stopniu „samodzielności” dzieła Wujka (jeśli to on był autorem komentarzy, o czym w dalszej części artykułu).

O ile wszechobecne od końca lat osiemdziesiątych XVI wieku Disputationes de controversiis Christianae Fide ${ }^{22}$ jawią się jako naturalne źródła wykładu katolickiej doktryny i jej zakorzenienia w Piśmie Świętym oraz oczywiste opracowania polemiki z protestantami na gruncie biblijnym, o tyle może dziwić wybór angielskiego tłumaczenia Nowego Testamentu. Po pierwsze, ze względu na (pozorną?) odległość kulturowa, po drugie - z powodu dużego stopnia zależności paratekstu NT1593 od tego źródła.

Już samo powierzchowne porównanie zawartości i typografii obu wydań pokazuje, że polscy jezuici (a przynajmniej Wujek) musieli postrzegać DRNT jako świetny wzór, wart emulacji. Jak głębokie jednak jest podobieństwo? Frick tak podsumowywał wyniki swoich analiz (pozwalam sobie na przytoczenie obszernego fragmentu, ponieważ praca tego badacza pozostaje w Polsce praktycznie nieznana):

Dług, jaki Wujek zaciągnął w rekuzanckim modelu, był daleko większy, niż przyznał sam tłumacz, tzn. sięgał poza annotacje do poszczególnych wersetów, umieszczone na końcu każdego rozdziału pod nazwą Nauk i przestróg. Wersja Wujka zawiera tabelę, zatytułowaną Summa i porzadek historyjej Ewangelijej świętej, ze czterech Ewangelistów zebrany, i na swe części i lata, których się co działo, rozdzielony [...], której pod względem typografii i zawartości blisko odpowiada The Summe, and the Order of the

18 R. Pietkiewicz, Biblia Polonorum. Historia „Biblii” $w$ języku polskim. T. 1: Od początku do 1638 roku. Poznań 2016, s. 465-469. Zob. R. P i t t k i ew i c z, Polskie antytrynitarskie przekłady „Biblii” $w$ dialogu Pierwszej Rzeczypospolitej ze wschodnia i zachodnia Europa. W zb.: Antytrynitaryzm w Pierwszej Rzeczypospolitej w kontekście europejskim. Źródła-rozwój-oddziaływanie. Red. M. Choptiany, P. Wilczek. Warszawa 2017, s. 273, przypis 35.

19 P. Nicko-Stępi é, Źródta dla komentarza tekstowego „Nowego Testamentu” $w$ tłumaczeniu Jakuba Wujka z roku 1593. Studium Dz 2, 14-36. „Odrodzenie i Reformacja w Polsce” 2017.

20 Zob. T. Ru bi k, „Disputationes de controversiis Christianae Fidei” Roberta Bellarmina jako źródło komentarzy do „Pisma Świętego” przekładu Jakuba Wujka. Problematyka pośrednich zapożyczeń z „Disputationes” na przyktadzie Augustyna Biesiekierskiego. „Terminus” 2018, z. 1 (w druku).

21 Zob. Fri ck, Anglo-Polonica, s. 55-61. - N i c k o-S tę p i en, Źródła dla komentarza tekstowego „Nowego Testamentu” $w$ tłumaczeniu Jakuba Wujka z roku 1593, s. 253.

22 Zob. P. U rbań ski, Roberto Bellarmino (1542-1621) i wpływ jego myśli na rozwój kulturowych oraz religijnych idei $w$ Rzeczypospolitej. W zb.: Formowanie kultury katolickiej $w$ dobie potrydenckiej. Powszechność i narodowość katolicyzmu polskiego. Red. J. Dąbkowska-Kujko. Warszawa 2016, s. 192-204. 
History of the Evangelical historie: gathered briefly out of all foure, even unto Christs Ascencion, zamieszczona w reimskiej wersji. Ponadto podobne tabele poświęcone „sprawom dwóch przedniejszych apostołów" [tj. Piotra i Pawła] znajdują się w obu wydaniach.

Zarówno wersja Wujka, jak i reimskie tłumaczenie, zawierają [...] Summę Nowego Testamentu i czterech Ewangelii, podsumowania [...] każdej księgi Nowego Testamentu, poza tym jedno ogólne omówienie Listów Apostolskich. Wiele z tych opisów w przekładzie Biblii Wujka odwzorowuje tekst angielskiego Nowego Testamentu, czasem na zasadzie dosłownego tłumaczenia, czasem parafrazy bądź adaptacji $[\ldots]$.

Np. Wujkowa Summa Nowego Testamentu pozostaje bardzo blisko tekstu zamieszczonego w reimskiej Summe of the New Testament [...], jest to prawie dosłowne tłumaczenie trzech różnych elementów reimskiego tekstu [...].

Summa czterech Ewangelii, która znajduje się zaraz niżej, jeszcze na tej samej stronicy, odsłania nieco inne podejście - zaczyna się od luźnej adaptacji reimskiej Summe of the 4 Gospels, by zaraz, w drugim akapicie, powrócić do bliskiego przekładu [...].

Podobny obraz przedstawiają annotacje do poszczególnych wersetów, a więc obszar, w którego wypadku Wujek wskazał na swoje zadłużenie względem reimskiego modelu. [...] Moje ogólne wrażenie jest takie, że Wujek ściślej stosował się do wzoru na początku. Niemniej jednak widać, że angielski Nowy Testament miał cały czas przed oczami [...].

Wygląda na to, co jest może bardziej zaskakujące, że Wujek zaczerpnął fragment z przedmowy do reimskiego Nowego Testamentu $[\ldots]^{23}$.

Takie zbieżności rodzą szereg pytań, sproblematyzowanych w większości również przez Fricka: 1) czy na pewno to właśnie DRNT stało się wzorem dla polskiego Nowego Testamentu, tzn. czy można wykluczyć istnienie wspólnego źródła?; 2) jeśli tak, to dlaczego właśnie DRNT?; 3) czy Wujek znał język angielski, tj. czy samodzielnie przekładał odpowiednie fragmenty z DRNT, czy może korzystał z czyjejś pomocy $^{24}$ ?

Stopień zbieżności DRNT i NT1593 (przede wszystkim fragmenty „dosłownego tłumaczenia”) oraz wskazanie w przedmowie pochodzenia komentarzy zdają się wykluczać hipotezę wspólnego źródła. Ewentualna podstawa „annotacyj” znajdujących się w DRNT nie została dotychczas zidentyfikowana ${ }^{25}$. Trudno wyobrazić sobie powód, dla którego Wujek miałby ukrywać inne źródło (zapewne łacińskie i bez wątpienia katolickie) pod maską DRNT - wydania, które spędzało sen z powiek angielskim protestantom ${ }^{26}$ - i to jeszcze tuż obok wzmianki o Disputationes de controversiis Christianae Fidei, dziele, które $z$ kolei spędzało sen z powiek protestantom w całej Europie ${ }^{27}$. Warto jednak pamiętać o tej hipotezie, nie da się bowiem na tym etapie badań wykluczyć możliwości (aczkolwiek mało prawdopodobnej), że DRNT posłużyło wyłącznie do wskazania fragmentów godnych uwagi we wspólnym źródle. Hipotezę tę osłabia ponadto fakt błyskawicznej i szerokiej recepcji DRNT (o czym dalej).

Frick, Anglo-Polonica, s. 56-58.

Zob. Fri c k, Anglo-Polonica, s. 61-63. Pytania postawione przez badacza formułuje również Pi e tki ew i z (Biblia Polonorum, s. 469).

Zob. np. J. P. M a r m i o n, Gregory Martin. The Origins and Influence of His Criticisms. „Scripture” $1968, \mathrm{nr} 52$.

Zob. np. H. Po pe, English Versions of the Bible. London 1952, s. 273-293.

Zob. P. Kr a s ny, Visibilia signa ad pietatem excitantes. Teoria sztuki sakralnej $w$ pismach Roberta Bellarmina, Cezarego Baroniusza, Rudolfa Hospiniana, Fryderyka Boromeusza i innych pisarzy kościelnych epoki nowożytnej. Kraków 2010, s. 115-118. - U rb ań s ki, op. cit., s. 192. 


\section{Dlaczego DRNT mógł posłużyć jako źródło?}

Wokół relacji między Polakami a Brytyjczykami, zarówno protestantami, jak i katolikami, narosła obfita literatura przedmiotu ${ }^{28}$. Wiedza na ten temat $z$ pewnością nie jest jednak kompletna, czego dowodzi choćby nierozpoznanie związków NT1593 z DRNT. W sprawy Kościoła w Anglii angażowali się żywo Jan Łaski (młodszy) i Stanisław Hozjusz, którego pisma jeszcze w latach sześćdziesiątych XVI wieku tłumaczono na język angielski. Założone przez niego kolegium w Braniewie do 1620 roku pozostawało jedną $z$ najważniejszych instytucji służących kształceniu angielskiej młodzieży na kontynencie ${ }^{29}$. William Allen, bliski współpracownik kardynała, utworzył seminarium w Douai ${ }^{30}$ i powołał tam do życia ośrodek, w którym później, po uzyskaniu zgody od papieża Grzegorza XIII, sam zainicjował przekład Biblii na język angielski (DRNT; Stary Testament, choć ukończony wcześniej, ukazał się dopiero w początku XVII wieku). Allen pomagał także przy pracach translatorskich ${ }^{31}$.

Do końca XVI wieku 22 jezuitów szkockiego i angielskiego pochodzenia znalazło schronienie w Rzeczypospolitej, kiedy protestanckie prześladowania zmusiły ich do opuszczenia Wysp Brytyjskich (podobnie jak wielu protestantów, którzy przybyli do Rzeczypospolitej z powodu szykan ze strony katolików). Żywo uczestniczyli w organizacji jezuickiego szkolnictwa ${ }^{32}$. Znane jest również duże zainteresowanie Piotra Skargi sytuacja na Wyspach Brytyjskich, autor ten wskazywał nawet na pewne podobieństwa sytuacji wyznaniowej obu regionów ${ }^{33}$.

Frick zauważył ciekawą zbieżność w powstaniu DRNT i NT1593. Oba przekłady były przez swoich inicjatorów i twórców postrzegane jako wymuszone przez protestanckie przedsięwzięcia przekładowe i wydawnicze. Stanowiły ogniwa serii anglo- i polskojęzycznych tłumaczeń Biblii. Jak ujmowali ich autorzy: to, co nie jest dobre dla człowieka zdrowego (a chodzi o udostępnianie wernakularnego Pisma Świętego maluczkim), może okazać się niezbędnym lekarstwem w chorobie. Taka metafora pojawiła się w Wujkowej Postylli katolicznej, w przedmowie do DRNT oraz w Apparatus sacer, przedmowie do B1599 ${ }^{34}$, napisanej prawdopodobnie przez Marcina Łaszcza (jak podaje Pietkiewicz ${ }^{35}$ ). Okręt Kościoła natrafił na nie znane wcześniej rafy. Zarówno jego polscy, jak i angielscy sternicy musieli dokonać korekty kursu wyznaczonego im przez traktat Hozjusza De expresso Dei verbo [...] libellus i jego angielski przekład pióra Thomasa Stapletona, Of the Expresse Worde of God [...] Treatyse z 1567 roku. Kardynał uważał tłumaczenie Pisma Świętego na języki

Zob. M. H a nu si ew i c z-Lav alle e, Brytania i Sarmacja - na krańcach Europy. W zb.: Wśród krajów pótnocy. Kultura Pierwszej Rzeczypospolitej wobec narodów germańskich, słowiańskich i naddunajskich: mapa spotkań, przestrzenie dialogu. Red. ... Warszawa 2015. Ibidem, s. 133.

Zob. E. D u ffy, William, Cardinal Allen, 1532-1594. „British Catholic History” 1995, z. 3, s. $272-$ 280.

Zob. Po pe, op. cit., s. 250-251.

Zob. H a n u s i ew i c z-La vall e e, op. cit., s. 136-137 i bibliografia zawarta w przypisie 31, s. 137.

Zob. Frick, Anglo-Polonica, s. 50. - U. Sz u m s ka, Anglia a Polska w epoce humanizmu i reformacji. (Zwiazki kulturalne). Lwów 1938, s. 98-102.

Zob. Frick, Anglo-Polonica, s. 55.

Piet ki ewi cz, Biblia Polonorum, s. 465. 
wernakularne za bezwarunkowo nieodpowiednie, bo stwarzające śmiertelne zagrożenie dla dusz maluczkich i dla jedności Kościoła ${ }^{36}$.

Frick przypuszczał, że propozycja podjęcia pracy nad nowym katolickim przekładem w środowisku polskich jezuitów w 1584 roku mogła mieć związek z powstaniem DRNT i z jego błyskawiczną recepcją w Anglii (o czym dalej), które w istocie mogły zrodzić podobna ideę w kręgach jezuickich, a więc międzynarodowych ${ }^{37}$.

Jeśli jednak - co ze względu na bardzo szybką wymianę informacji między ośrodkami jezuickimi jest mało prawdopodobne - o DRNT w ogóle w Polsce nie słyszano przed podjęciem inicjatywy translacji (co miało miejsce na kongregacji prowincjonalnej Towarzystwa Jezusowego w Kaliszu w maju 1584) ${ }^{38}$, wydaje się niemożliwe, żeby Wujek nie dowiedział się o nim w Rzymie. Wybrał się tam w końcu 1584 roku, żeby uzyskać na przekład zgodę od papieża Grzegorza XIII, tego samego, który kilka lat wcześniej udzielił pozwolenia na tłumaczenie katolikom z Douai-Reims.

W tamtym momencie publikacja DRNT stanowiła stosunkowo nowe wydarzenie, środowisko rekuzantów zaś ściśle współpracowało ze Stolica Apostolską ${ }^{39}$. DRNT był postrzegany przez brytyjskich protestantów jako tak niebezpieczny, że jego posiadaczy wtrącano do więzień i często poddawano torturom ${ }^{40}$. Jego tłumacz, Gregory Martin, wydał w Reims jeszcze w 1582 roku - a więc w tym samym, co DRNT - dzieło Discouerie of the Manifold Corruptions of the Holie Scriptures by the Heretikes of our daies, specially the English Sectaries [...], demaskujace fałszerstwa, jakie mieli wprowadzać protestanci do przekładów Pisma Świętego. Już w 1583 roku odpowiedział na nie William Fulke, który wcześniej polemizował z Hozjuszem w pracy Ad epistolam Stanislai Hosii [...] „De expresso Dei verbo” responsio (1578). Polemiki $z$ traktatem Martina ukazywały się do 1626 roku $^{41}$. Ferment zapoczątkowany wydaniem DRNT doprowadził w końcu do powstania Biblii Króla Jakuba w 1611 roku. Była ona - jak wynika $z$ najnowszych ustaleń - zależna od tłumaczenia DRNT również pod względem pewnych decyzji translatorskich ${ }^{42}$. Autorem „annotacyj” w DRNT był Richard Bristow ${ }^{43}$.

Jest oczywiste, że gwałtowna i błyskawiczna reakcja, świadcząca o tym, jak celny sztych wymierzyli brytyjskim protestantom szermierze kontrreformacji z DouaiReims, nie mogła ujść uwadze Watykanu. Nie wydaje się prawdopodobne, by polscy jezuici, na co dzień współpracujący z angielskimi i szkockimi braćmi, nie słyszeli o wspominanym Nowym Testamencie przed 1584 rokiem, a tym bardziej by Wujek nie miał żadnej okazji zapoznać się z nim w Rzymie. O ile więc można bezpiecznie przyjąc, że DRNT stanowiło w jakiejś mierze wzór dla dzieła Wujka, o tyle wolno również przypuszczać, iż takie założenie towarzyszyło tłumaczowi co najmniej od momentu jego wizyty w Rzymie.

Zob. np. F r i c k, Polish Sacred Philology in the Reformation and the Counter-Reformation, s. 36-44. Frick, Anglo-Polonica, s. 63.

Zob. np. Poplatek, op. cit., s. 53.

Zob. np. Duffy, op. cit., passim. - Marmi o n, op. cit., passim. - Po pe, op. cit., s. 249-272.

Zob. Po pe, op. cit., s. 275.

Zob. ibidem, s. 273-293.

Zob. G. C a m p be1l, The Catholic Contribution to King James Bible. $\mathrm{W}$ zb.: The English Bible in the Early Modern World. Ed. R. Armstrong, T. Ó hAnnracháin. Leiden-Boston 2018.

Zob. Po pe, op. cit., s. 252-253. 
Problem pozostaje otwarty, nie można bowiem wykluczyć, że uda się natrafić na inne echa recepcji DRNT bądź Discouerie of the Manifold Corruptions [...] Martina w ówczesnej Rzeczypospolitej, co jeszcze bardziej wzmocniłoby taką hipotezę. Istnieja świadectwa adaptacji najnowszej literatury rekuzanckiej właśnie w tym okresie, np. przez Skargę w Żywotach świętych ${ }^{44}$. Z kolei Okrucieństwo kacyrskie przeciw katolikom $w$ Anglijej z 1582 roku, odzwierciedlające wydarzenia $z$ misji jezuickiej do Anglii zorganizowanej przez samego Allena w 1580 roku, to przekład dzieła Roberta Personsa (bądź Parsonsa), napisanego jedynie rok wcześniej. Uświadamia to szybkość wymiany informacji. Tłumaczenie to ukazało się $n b$. w Poznaniu $^{45}$, gdzie przez znaczny odcinek lat osiemdziesiatych XVI wieku Wujek pracował nad przekładem Biblii.

\section{Czy Jakub Wujek znał język angielski?}

Zależność dużej części aparatu NT1593 od DRNT naturalnie prowokuje pytanie, czy Wujek znał język angielski. Frick pisał:

Ale czy Wujek korzystał z reimskich komentarzy i przedmowy w ich angielskim kształcie? Nie znajduję wewnątrz tekstu żadnego dowodu, by odpowiedzieć na to pytanie ani twierdząco, ani przecząco. [...] Można sobie wyobrazić, że Wujek, postawiony w obliczu konieczności, mógł podjąć udaną próbę rozwiązania zagadki angielskiego tekstu takiego, jak reimskie annotacje, zwłaszcza że główny „wątek” byłby mu dobrze znany.

Ważne jest jednak, że nie było potrzeby, by Wujek samodzielnie dokonywał translacji z angielskiego. [...] ze względu na ilość przetłumaczonego materiału, wysoka jakość przekładu, obecność dobrze wykształconych jezuitów, którzy posługiwali się językiem angielskim i byli zorientowani w osobliwościach sytuacji w Polsce, oraz ze względu na małe szanse, by Wujek znał ów język obcy chociaż na podstawowym poziomie, jeśli w ogóle, pozostaje wysoce prawdopodobne, że mamy tutaj do czynienia z przykładem współpracy między angielskimi bądź szkockimi a polskimi jezuitami. Z pobytów w Poznaniu, Braniewie, Krakowie i Wilnie Wujek mógłby znać kilku anglojęzycznych braci zakonnych, którzy byli dobrze zorientowani w okolicznościach, jakie panowały w Rzeczypospolitej, i mogliby mu pomóc ${ }^{46}$.

Zarówno nowe studia dotyczące omawianej zależności tekstowej (które od czasu artykułu Anglo-Polonica... Fricka nie poszerzyły ani nie pogłębiły wiedzy na ów temat), jak i oparta na materiale archiwalnym znajomość faktografii nie pozwalają rozstrzygnąć tej kwestii. Dlatego nie mogę zgodzić się z konkluzjami Nicko-Stępień:

Wujek [...] najprawdopodobniej znał jezzyk angielski.

Jeśli zaś chodzi o znajomość języka angielskiego, to istnieje duże prawdopodobieństwo, że Wujek sam się go nauczył, aby w swojej pracy opierać się na tekstach z Nowego Testamentu z Reims. Przebywając w międzynarodowym środowisku jezuickim i posiadając talent do nauki języków obcych, mógł opanować angielski, żeby pracować samodzielnie i nie korzystać z pomocy jakiegoś współbrata Anglika. Wprawdzie u jezuitów nie brakowało wówczas zakonników angielskiego pochodzenia, jednak brak źródeł, które jednoznacznie wskazywałyby u Wujka na fakt posługiwania się wsparciem anglojęzycznego tłumacza.

Wujek nie wspomina o tym w ogóle w swojej korespondencji listownej z przełożonymi. Można

Zob. np. Hanusiewicz-Lavalle e, op. cit., s. 138-143.

Zob. M. Hanusiewicz-Lavalle e, „Okrucieństwo kacyrskie przeciw katolikom w Anglijej”, czyli polski głos w sporze o męczeństwo. „Odrodzenie i Reformacja w Polsce” 2012.

F ri c k, Anglo-Polonica, s. 62-63. 
przypuszczać, że gdyby korzystał z pomocy angielskiego tłumacza, to zawarłby tę informację w swoich sprawozdaniach $[\ldots]^{47}$.

Jeśli jezuici postrzegali DRNT jako wzór zasługujący na naśladowanie (co wydaje się najbardziej prawdopodobne), Wujek - wyznaczony do przełożenia Biblii, w pierwszej kolejności Nowego Testamentu - faktycznie mógł opanować angielski. I w tym wypadku, jak można przypuszczać, potrzebowałby jednak wsparcia ze strony osoby władającej tym językiem. Trudno też wyobrazić sobie sytuację, aby tłumacz uczył się angielskiego, żeby w ogóle się dowiedzieć, co kryje tekst, na którym ma pracować. Brak źródeł wskazujących na udział innego jezuity znającego język angielski nie może być traktowany jako argument na rzecz hipotezy o posługiwaniu się przez Wujka tym językiem na jakimkolwiek poziomie. Dostępne materiały archiwalne, zwłaszcza korespondencja Wujka, zachowane są w niewielkim stopniu, ponadto - jak uważam - nie zostały wystarczająco wykorzystane przez badaczy, podobnie jak przedmowy do wydań przekładów biblijnych (o czym dalej). Poza tym tłumacz równie dobrze mógł nie chcieć zaprzątać głowy generałowi Claudiowi Aquavivie niekoniecznie istotną dla niego informacją. A wszystkie znane dziś listy $\mathrm{z}$ lat 1585-1597, czyli z okresu, kiedy Wujek pracował nad przekładem (z wyjątkiem jednego pisma do Paula Campana oraz krótkiej notatki bez określonego odbiorcy), adresowane były właśnie do generała ${ }^{48}$.

Skąd jednak w ogóle wiadomo, że to Wujek jest autorem komentarzy?

\section{Czy Wujek napisał (bądź przetłumaczył) komentarze do Nowego Testamentu?}

Według konsensu badaczy to Wujek był twórcą komentarzy do swojego przekładu Biblii. Nikt nie rozważał w ogóle innej możliwości; nikt, oprócz - znowu - Fricka, który postawił takie pytanie. Stwierdził wszakże, iż nie istnieje powód wystarczający, by przypuszczać, że ktoś inny odpowiadał za finalny kształt paratekstu. Wujek musiał być, co najmniej, jego ostatecznym „redaktorem” (w wypadku, gdyby korzystał z czyjejś pomocy w tłumaczeniu komentarzy z DRNT) ${ }^{49}$.

Jakkolwiek absurdalnie to brzmi, warto zapytać, czy znamy jakiekolwiek źródło mówiące wprost o Wujku jako twórcy komentarzy w NT1593 i tzw. Biblii Wujka. Karty tytułowe przypisują mu autorstwo zarówno samego przekładu, jak i „, nauk i przestróg” (NT1593), ,annotacyj” (PS1594) oraz „katolickiego wykładu” (B1599) ${ }^{50}$. Skądinąd wiadomo jednak, że karty tytułowe nie zawsze dokładnie i poprawnie przedstawiały autorstwo. Ponieważ przekłady i rolę tłumacza w XVI wieku postrzegano zupełnie inaczej niż obecnie, karty tytułowe, zwłaszcza ówczesnych tłumaczeń, mogą teraz wydawać się mylące. Dobry przykład podobnej sytuacji stanowi rozprawa - by nie szukać daleko - O Bóstwie Syna Bożego i Ducha Świętego [...] dowody

N i c k o - S t ę p i eń, Źródła dla komentarza tekstowego „Nowego Testamentu” $w$ tłumaczeniu Jakuba Wujka z 1593 roku, s. 235, 253-254, s. 254, przypis 22.

48 Korespondencja ks. Jakuba Wujka z Wagrowca z lat 1569-1596 (ciag dalszy). Podług autografów wydał i objaśnił J. Syg ański. „Roczniki Towarzystwa Przyjaciół Nauk Poznańskiego” 1920. Poplatek, op. cit., s. 83-91. 
rozmaite z „Pisma Świętego”, $z$ doktorów i synodów wszytkich wieków [...] zebrane [...] przez Jakuba Wujka, wydana w Krakowie w 1590 roku. Dziełko to było w istocie przeróbką wywodu Bellarmina, o czym jednak i na karcie tytułowej, i wewnątrz tekstu nie znajdzie się wzmianki ${ }^{51}$.

Zastosowanie tego typu analogii do kart tytułowych druków biblijnych nie uprawniałoby do podania w wațliwość Wujkowego autorstwa komentarzy. Podstawą takich domysłów może być wszakże analiza tekstu przedmów: do NT1593, Nowego Testamentu z 1594, PS1594 oraz B1599.

W przytoczonym wcześniej fragmencie przedmowy do NT1593 Wujek informował, że komentarze „są zebrane” z DRNT i Disputationes de controversiis Christianae Fidei. Jest to jedno $\mathrm{z}$ kilku miejsc, w których pojawia się tego typu formuła, nie przypisująca jakiejś czynności danemu autorowi bądź grupie. Inaczej w wypadku pracy wykonanej przez konkretną osobę (przeważnie przez samego Wujka), „błędów” popełnionych przez poszczególnych tłumaczy protestanckich lub dokonań ogółu katolickich uczonych. To Wujek zwraca się do odbiorcy, wyjaśniając mu okoliczności powstania przekładu i omawiając „fałszerstwa heretyckie” 52 :

chrześcijańskiemu czytelnikowi Jakub Wujek [...] łaski Pana Naszego [...] wiernie życzy i winszuje.

widze, iż sama rzecz tego potrzebuje [...], czytelniku, abym Ci dał sprawę [...] co mię do tego przywiodło, abych się tak wielkiej i poważnej [...] prace [...] podjął. [s. LI; zob. też np. s. LVI-LVII, LX, LXIII-LXIV]

Tłumacz dokładnie i po kolei wymienia czynności, które wykonał sam, np.:

co się dotyczy ksiąg, z którychem przekładał: aczem zaraz z greckiego i łacińskiego języka przekładał, wszakżem w tekście wszędy Nowego Testamentu nie greckiego, ale łacińskiego starego [...] naśladował. [s. LVII]

gdziekolwiek się co w greckim tekście inaczej najdowało, tom ja wszędy [...] na brzegu pokazał. Bo gdzie co więcej w greckim niż w łacińskim było, tom gwiazdką naznaczył [...]. Gdzie zasię którego słowa [...] w greckim tekście nie było [...], tedym naznaczył rożenkiem tak w tekście [...]. [s. LXIII; zob. też np. s. LVI, LXIII-LXIV, LVI-LXVII]

W kilku z tego typu fragmentów wyraźnie daje się odczuć duma Wujka: tytuły niektóre listów Pawła św. wyraziłem, jako mniemam, właśniej i grzeczniej [...]. [s. LXVII] są na brzegu różnice drugie ode mnie samego znaszając tekst grecki królewski z łacińskim obaczone i naznaczone, których Biblia Plantynowa nie ma. [s. LXIX]

„Biblia Plantynowa” to Wulgata lowańska z 1574 roku, z której Wujek skopiował dużą część variae lectiones. Jak napisał o tym sam tłumacz? „[Na marginesach] znaczą się różne czytania od lowańskich teologów z rozmaitych ksiąg [...] zebrane i naznaczone" (s. LXVIII). Widać więc, że w miejscach, w których Wujek korzystał z owoców pracy wykonanej przez kogo innego, wycofywał się z form pierwszej osoby liczby pojedynczej. Dokładnie tak samo wyraził się o „summach” ksiag i rozdziałów, a więc kolejnej części paratekstu zaczerpniętej z DRNT: „przed każdymi zasię

51 Urbańs ki, op. cit., s. 201-202.

52 Cytując z NT1593 i z edycji z 1594 roku, korzystam z przywoływanego już w przypisie 2 wydania z 1966 roku, opracowanego przez W. S m e r e kę. Lokalizacje z NT1593, PS1594 i B1599 podaję w nawiasach po cytatach. 
księgami summy ich, jako i przed każdym rozdziałem argumenta, abo summy rozdziału każdego są położone i liczbami wierszów poznaczone [...]” (s. LXX).

Również autorstwa „summy” i synopsy Ewangelii, spisu czynności z Dziejów Apostolskich oraz indeksu Wujek nie przyznawał sobie:

Przydaliśmy też na początku summę i porządek historyjej Ewanjelijej [...]. [s. LXX-LXXI]

Tymże sposobem na dwu tabliczkach spisaliśmy porządnie dzieje, sprawy, drogi i pielgrzymowania przedniejszych dwu apostołów Pańskich [...], które najdziesz po Dziejach Apostolskich położone. [s. LXXI]

Na koniec położyliśmy na końcu rejestr dostateczny wszystkich nauk i rzeczy zbawiennych, które się w tych świętych księgach Nowego Testamentu zamykają. [s. LXXI]

To jedne $z$ niewielu miejsc, w których pojawia się pierwsza osoba liczby mnogiej. Nie sądzę, by można było ją rozumieć jako pluralis modestiae; byłby to dziwny zbieg okoliczności, gdyby jedyne w przedmowie frazy tego typu odnosiły się akurat do elementów, w których wypadku przekonanie o autorstwie (czy samodzielności pracy) Wujka sfalsyfikowano bądź kwestionowano. Jeśli we wcześniejszych fragmentach przedmowy występuje pierwsza osoba liczby mnogiej, odnosi się ona przeważnie albo do „nas, katolików” (zob. np. s. LII-LIV, LVII), albo do „nas, jezuitów”, w szczególności w kontekście podjęcia pracy nad nowym przekładem Biblii (zob. np. s. LI-LIII).

Również w przedmowie do „popularnej” edycji Nowego Testamentu z 1594 roku Wujek nie przypisuje sobie autorstwa paratekstu w NT1593:

po wydaniu Nowego Testamentu przez mię przeszłego roku z łacińskiego i z greckiego języka na polski przełożonego z przydaniem annotacyj, Czytelniku miły, umyśliłem był zaraz wydać tenże tekst Nowego Testamentu bez żadnych annotacyj, na mniejsze modum [...]. [s. LXII]

Fraze „przez mię” odnosić można do „wydania Nowego Testamentu [...] z przydaniem annotacyj” (Wujek jawiłby się więc jako redaktor wydania) lub „przełożonego z przydaniem annotacyj", lecz w obu tych wypadkach nie wskazuje to jednoznacznie, by Wujek był „annotacyj” twórcą.

Apparatus sacer, przedmowa do B1599, napisana prawdopodobnie przez Łaszcza, wręcz rozłącza tłumaczenie - dzieło Wujka - od aparatu egzegetyczno-apologetycznego. Autor wstępu w jednym akapicie wspominał: „przydane sa wykłady miejsc trudniejszych”, dopiero w kolejnym informował zaś:

kończąc już tę przedmowę, Czytelniku miły, przypomnęć jednę rzecz dla pociechy twojej. Autor, który tę Biblia wszytkę przetłumaczył, był ks. Jakub Wujek, teolog Societatis Iesu [... $]^{53}$.

Zupełnie inaczej wygląda to w przedmowie do PS1594. W niej, jak i w NT1593, Wujek w pierwszej osobie (i znowu z uzasadnioną dumą wybitnego uczonego) omawia wykonana przez siebie pracę, do której w tym wypadku należy także przygotowanie paratekstu wydania:

Do wykładu [...] Psalmów i ku objaśnieniu wszytkich miejsc trudniejszych, tychem autorów najwięcej używał, którzy literalem sensum z oryginalnych języków, greckiego i żydowskiego, najlepiej wykładają, jako Genebrardus, Jansenius, Pagninus [...]. 
Przydałem i argumenty albo summy psalmów co nakrótsze, nawięcej z Genebrarda [... $]^{54}$.

Kontrast z przytoczonymi wcześniej fragmentami przedmowy do NT1593 jest ewidentny. Prawdopodobieństwo pracy nad paratekstem tego wydania w kilkuosobowym zespole wydaje się bardzo duże.

Warto przypomnieć też wątpliwość, jaką z Aquavivą dzielił się Ludovico Maselli w liście z 20 VII 1592, a więc w czasie, kiedy kolejne arkusze Nowego Testamentu wychodziły już drukiem:

Są pewni, którzy mają wątpliwość, czy wydanie Nowego Testamentu, które teraz jest pod prasa, powinno być poprzedzone imieniem ojca Jakuba Wujka, który najwięcej przełożył, czy zaś [należy je] przemilczeć, żeby dowiedziano się, że [Nowy Testament] został przełożony przez wielu z Towarzystwa, nie jednego. Nie wiem, co Wasza Najprzewielebność o tej rzeczy uważa ${ }^{55}$.

Aquaviva zdecydował o umieszczeniu nazwiska Wujka na karcie tytułowej. Dotychczas słowa: „żeby dowiedziano się, że [Nowy Testament] został przełożony przez wielu z Towarzystwa, nie jednego", interpretowano wyłącznie jako odnoszace się do roli cenzorów ${ }^{56}$ - pracę Wujka bowiem kontrolowała i weryfikowała grupa współbraci, co stanowiło jeden $z$ warunków postawionych przy zgodzie na przekład ${ }^{57}$. Drzymała widział w tym fragmencie wręcz pomysł taktycznego zabiegu: „niektórzy wyrażali wątpliwość [...] czy może lepiej będzie je [tj. nazwisko Wujka] pominąć, aby czytelnicy sądzili, że tłumaczenia dokonało kilku członków zakonu"58. Wzmianka Masellego o wątpliwościach „niektórych” jest bardzo enigmatyczna. Nie ma wystarczających przesłanek, by twierdzić, że odnosi się ona - wyłącznie bądź w ogóle - do udziału cenzorów w weryfikacji przekładu, a nie narodziła się w związku ze współdziałaniem Wujka z innymi jezuitami przy przygotowaniu aparatu krytycznego.

Jak wskazywał Frick, Wujek naprawdę nie musiałby długo szukać odpowiedniego współpracownika. Jeśli faktycznie korzystał z czyjejś pomocy, mógł to być np. rezydujacy m.in. w Braniewie brat William Lambert, o którym jako o jedynym z anglojęzycznych jezuitów w Rzeczypospolitej wiadomo, że znał język polski, choć „none well [niedoskonale]”, jak podał David Lenaghan za źródłem z Archivum Romanum Societatis Iesu ${ }^{59}$. Mógł to być również Laurence Arthur Faunt, nb. „pu-

Wuj ek, przedmowa w: PS1594, s. 14-15.

L. M a s elli, list do C. Aquavivy. Cyt. za: Po pla te k, op. cit., s. 61, przypis 24 (wersja oryginalna: „Sunt aliqui, qui dubitant, an versioni Novi Testamenti, quae nunc sub praelo est, debeat praefigi nomen $P\langle$ atris〉 Iacobi Wuieci, qui potissimum vertit, an vero taceri, ut intelligatur a pluribus de Societate, non ab uno versum. Nescio, quid P(aternitas〉 V〈estra〉 ea de re sentiat"). Zob. też D r zym a ła, Wpływ ks. Stanisława Grodzickiego T. J. na tłumaczenie „Biblii” ks. Jakuba Wujka T. J., s. 74, przypis 8.

Zob. Frick, Anglo-Polonica, s. 62. - Pi et ki ew i c z, Biblia Polonorum, s. 457, literatura w przypisie 701 na tejże stronicy.

Na temat ingerencji cenzorów w przekład Wujka zob. m.in. Drzy mała, Wpływ ks. Stanisława Grodzickiego T. J. na tłumaczenie „Biblii” ks. Jakuba Wujka T. J., passim. - G ą s i o r ow s ki, op. cit., passim. - Frankowski, op. cit., passim. - T. Rubik, „Zgromadzenie marnych” - „zbór marności”. Ingerencja cenzorów $w$ „Psałterz” przekładu Jakuba Wujka. W zb.: Figura heretyka w nowożytnych sporach konfesyjnych. Red. A. Bi ela k, W. Ko r d y z o n. Warszawa 2017, passim. D r zy mała, Wpływ ks. Stanisława Grodzickiego T. J. na ttumaczenie „Biblii” ks. Jakuba Wujka T. J., s. 74.

J. A. Le nag ha n, „The Sweetness of Polish Liberty”. Sixteenth-Century British Jesuit Exiles to Poland-Lithuania. „Reformation” 2010, s. 147. 
pil Williama Allena"60, przez około 10 lat (od 1581 do swojej śmierci w 1591 roku) wykładowca filozofii i teologii moralnej w poznańskim kolegium (gdzie przez znaczną część lat osiemdziesiątych XVI wieku przebywał Wujek ${ }^{61}$ ), autor licznych łacinskich publikacji z zakresu przede wszystkim teologii kontrowersyjnej. Omawiał w nich problemy Kościoła katolickiego w Polsce (doskonale więc orientował się w lokalnej sytuacji) i polemizował $\mathrm{z}$ ewangelikami augsburskimi oraz ewangelikami reformowanymi ${ }^{62}$. Prawdopodobnie już w 1582 roku pomagał polskiemu tłumaczowi Okrucieństw kacerskich przeciw katolikom $w$ Anglijej jako znający sprawe „konsultant"63, wiadomo też, że w 1585 roku współpracował z Wujkiem przy ocenie i cenzurze dzieła Antonia Possevina ${ }^{64}$.

W takim kontekście przekonujące wydają się rozważania Fricka, że Wujek musiał być (jeśli korzystał z językowego wsparcia współbraci) kimś w rodzaju ostatecznego redaktora całego paratekstu NT1593. Nie ulega wszakże wątpliwości, iż to on napisał przynajmniej część komentarzy, tych mianowicie, które uzasadniaja konkretne decyzje translatorskie, jak np. do Mt 2, 4 albo Dz 13, 2.

\section{Pytania i perspektywy badawcze}

Na tym - wstępnym - etapie ustaleń niewskazane jest wyciaganie daleko idących wniosków. Można natomiast postawić pewne pytania badawcze, a więc i opisać działania, jakie mogłyby dostarczyć na nie odpowiedzi. Niezbędne wydaje się również przeprowadzenie ponownej interpretacji dostępnego materiału archiwalnego.

1. Jakie teksty (w tym dotychczas wskazane) i w jaki sposób były wykorzystywane przez autora (autorów?) paratekstu NT1593 jako źródło pośrednie czy bezpośrednie?

Po zidentyfikowaniu wszystkich komentarzy, jakie przeniesiono $\mathrm{z}$, annotations" DRNT bądź opracowano na ich podstawie, możliwe będzie podjęcie dalszych poszukiwań źródłowych. DRNT wydaje się rodzić stosunkowo mało problemów, w tym wypadku analiza porównawcza byłaby zabiegiem prostym - polegałaby na zestawianiu kolejnych rozdziałów. Podobnie Postylla katoliczna, w dużej mierze uporządkowana według fragmentów biblijnych. Kluczowe na kolejnym etapie będa, oczywiście, Disputationes de controversiis Christianae Fidei Bellarmina. Niewykluczone jednak, że część z komentarzy okaże się pośrednio tylko zależna od tego kompendium, np. te $z$ nich, które mają charakter polemiki $z$ unitarystami, przez wykorzystanie wspomnianego dzieła Wujka O Bóstwie Syna Bożego i Ducha Świętego [...]. Dlaczego autor partii objaśnień opartych na Disputationes miałby nie sięgnąc po gotowa adaptację wywodu Bellarmina? Jeśli autorem był Wujek, dlaczego miałby nie wykorzystać już raz wykonanej pracy?

Szu m ska, op. cit., s. 115.

Zob. np. D. Kuźmin a, Jakub Wujek (1541-1597). Pisarz, tłumacz i misjonarz. Warszawa 2004, s. 151-198.

Zob. np. Szum ska, op. cit., s. 115-116.

H a n u s i e w i c z-La valle e, „Okrucieństwo kacyrskie przeciw katolikom w Anglijej”, czyli polski głos $w$ sporze o męczeństwo, s. 40-41.

Zob. list Jacob. Wujek Claudio Aquavivae, Praep. Generali S. J., Braunsberga 9 Maii 1585. W: Korespondencja ks. Jakuba Wujka z Wegrowca z lat 1569-1596, s. 46-47.

http://rcin.org.pl 
Narzędziem wymiernie ułatwiającym zidentyfikowanie nowych źródeł są umieszczane w wydaniach przekładu Wujka Regestry, zbierajace miejsca w Biblii, które odnoszą się do danego problemu, np. „zasług” (NT1593, k. dddddd 1). Pozwalają one określić tematyczne grupy komentarzy, co z kolei umożliwia ukierunkowanie poszukiwań źródłowych przez ograniczenie ich do chociażby jednego lub dwóch traktatów z Disputationes. Należy, oczywiście, pamiętać, że hasła w Regestrach nie muszą być kompletne (i część $z$ nich nie jest ${ }^{65}$ ), dlatego warto uzupełniać tematyczny korpus komentarzy na podstawie innych źródeł. Interesujacym pytaniem pozostaje, czy i jak często autorzy (nie tylko) katoliccy przy opracowywaniu swoich tekstów z tego typu spisów korzystali. Analiza porównawcza struktury argumentacji i siglów w odpowiednim korpusie tekstów apologetycznych bądź polemicznych z hasłami Regestrów mogłaby dostarczyć odpowiedzi na to pytanie.

2. Czy Jakub Wujek znał język angielski?

Uważam, że w świetle przedstawionej wcześniej argumentacji (w dużej mierze opartej na pracach Fricka), jako bardziej prawdopodobna jawi się hipoteza, iż Wujek nie władał językiem angielskim. Oczywiście, warto w tym kierunku prowadzić dalsze dociekania, ponieważ mogą one przynieść cenne ustalenia, dotyczace autorstwa komentarzy oraz sposobu adaptacji paratekstu DRNT (o czym również w punkcie 3).

Z pewnością do istotnych wniosków doprowadzić może analiza translatologiczna komentarzy z NT1593 zidentyfikowanych jako „literalne tłumaczenie” DRNT. Oczywiście trzeba tutaj brać pod uwagę prawdopodobieństwo ostatecznego opracowania językowego „annotacyj” przez Wujka. W każdym razie należy się spodziewać, że taka analiza pozwoliłaby wykazać, czy transfer językowy przebiegał:

a) równolegle $\mathrm{w}$ dwóch kierunkach $\mathrm{z}$ jednej podstawy, a więc ze wspólnego i bezpośredniego źródła paratekstu obu edycji Nowego Testamentu. Jeśli nie, umożliwiłoby to ostateczne oddalenie tej hipotezy;

b) wprost $z$ angielskiego do języka polskiego. Dowodziłoby to, że tłumacz tych „annotacyj” posługiwał się oboma językami, choć niekoniecznie świadczyłoby, że chodzi tu o Wujka;

c) pośrednio $z$ angielskiego do języka polskiego przez łacinę. Takie ustalenie dostarczyłoby dalszych przesłanek dla hipotezy, że komentarze opracowywały co najmniej dwie osoby, jedna znająca angielski i łacinę, druga - łacinę i polski.

Badania nad DRNT wykazały, iż część rozwiązań translatologicznych zastosowanych przez tłumaczy tego wydania miała nowatorski charakter i nie ograniczała się do wyboru wariantów $z$ wcześniejszych ogniw serii przekładowej66. Co więcej, pomysły te były cenione również przez protestantów (wbrew deklaracjom), czego dowodzi włączenie pewnych lekcji czy rozstrzygnięć leksykalnych do Biblii Króla $J a k u b a^{67}$. Może niektóre $z$ rozwiązań translatorskich zostały w NT1593 powtórzone za DRNT? Gdyby udało się zidentyfikować takie fragmenty przekładu Pisma komentarzy do „Pisma Świętego” przekładu Jakuba Wujka.

66 Zob. Pope, op. cit., s. 262.

67 Zob. Campbe11, op. cit., passim. 
Świętego, mogłyby one świadczyć o tym, że Wujek faktycznie znał angielski albo że konsultował swoją pracę $z$ kimś władającym tym językiem.

3. Kto był (współ)autorem paratekstu do NT1593?

Pewnych wskazówek co do ustalenia osoby potencjalnego współautora komentarzy (mianowicie co do jego kompetencji językowych) mogłaby dostarczyć omówiona w punkcie 2 analiza translatologiczna. Publikowane w Polsce dzieła angielskich i szkockich jezuitów, którzy z oczywistych względów jawią się jako pierwszorzędni kandydaci do pracy nad DRNT, sa, niestety, mało znane. Analiza komparatystyczna argumentacji w tych dziełach oraz komentarzy z NT1593 opartych na DRNT wskazałaby miejsca wspólne, a tym samym zawęziłaby zakres poszukiwań. Właściwą metoda byłaby analiza porównawcza tematycznych grup komentarzy z odpowiednimi tekstami łacińskimi, np. „annotacyj” dotyczących kontrowersji eklezjologicznych i prerogatyw władzy świeckiej oraz duchownej z traktatem Faunta De controversiis inter ordinem ecclesiasticum et secularem in Polonia [...] (pierwodruk w Poznaniu w 1587 roku).

Niewykluczone, że pewne kierunki w badaniach wytyczyłoby też porównanie stylistyczne komentarzy opartych na DRNT z pozostałymi objaśnieniami w NT1593, również przy użyciu komputerowych narzędzi stylometrycznych. Wyniki takiej analizy mogłyby jednak być niejednoznaczne, gdyby to Wujek jako redaktor nadał komentarzom ich ostateczny kształt.

4. Komentarze w PS1594 i B1599.

Jeśli wierzyć deklaracjom Wujka z przedmowy do PS1594, to właśnie on skomponował „annotacje” do Księgi Psalmów na podstawie innych tekstów, być może na zasadzie kompilacji czy przy użyciu kompendium nie zasygnalizowanego w przedmowie. Sytuacja jest bardziej problematyczna w wypadku komentarza do pozostałych ksiag Starego Testamentu, nie dysponujemy bowiem żadnymi wskazówkami ani co do ich źródeł, ani co do autorstwa (poza kartą tytułową).

Z moich badań nad tekstem komentarzy w obrębie Księgi Psalmów (porównania PS1594 i B1599) wynika, że korekty wprowadzone przez komisję cenzorów (bądź, w pewnych wypadkach, prawdopodobnie przez zecera) były bardzo nieliczne i polegały w większości na dostosowaniu fragmentu wersetu biblijnego, przytaczanego na początku komentarza, do nowego kształtu nadanego tekstowi przez cenzorów. Potwierdza to ustalenia Joanny Sobczykowej ${ }^{68}$. Pojedyncze zmiany sięgały głębiej, np. jedna z nich dotyczyła brzmienia cytowanego w komentarzu do Ps 113, 16 pierwszego przykazania. „Annotacja” z PS1594 pozwoliła więc zrekonstruować je do (prawdopodobnie) pierwotnej Wujkowej redakcji69. Modyfikowanie fragmentów w komentarzach nie przebiegało jednak w pełni konsekwentnie, niektóre $z$,wykładów" do Księgi Psalmów w B1599 zachowują zatem lekcje z 1594 roku. Nie usunięto również (przynajmniej części) komentarzy uzasadniających wprowadzenie przez Wujka do tekstu głównego odczytania z greki bądź z hebrajskiego w miejscach, gdzie tekst łaciński był zepsuty bądź niejasny. Dlatego w pewnych miejscach znajdujące się pod tekstem „wykłady” podważaja jego brzmienie (Ps 61, 10, Ps 77, 45) ${ }^{70}$. 
Zaobserwowanie podobnych zjawisk na kartach pozostałych ksiag Starego Testamentu pozwoliłoby stwierdzić, że - znowu - przynajmniej część z „wykładów” została napisana podczas prac nad przekładem, przypuszczalnie przez Wujka. Pobieżna lektura (żadną miarą nie mogąca, oczywiście, stanowić źródła informacji, a jedynie drogowskaz dla właściwej analizy tekstu) wskazuje, że pod kolejnymi rozdziałami Starego Testamentu jest znacznie mniej komentarzy niż w Nowym Testamencie, podobnie odsyłaczy do innych dzieł, od których roi się paratekst NT1593.

Nie ulega wątpliwości, że to przede wszystkim Nowy Testament „dostarczał paliwa" XVI-wiecznym kontrowersjom religijnym, pod tym względem Stary Testament był nieco mniej istotny, co zdaje się wyjaśniać wskazaną prawidłowość. Oczywiście można ją łączyć również z brakiem odpowiedniego wzoru czy źródła typu DRNT, którego paratekst nadawałby się do kompleksowej adaptacji. Może to w ogóle tekst „wykładów” ze Starego Testamentu (zwłaszcza z Psałterza) - paradoksalnie - jest „bardziej Wujkowy” niż tekst „annotacyj” z NT1593, a więc wydania kontrolowanego przez tłumacza?

Rozpoznanie problematyki źródeł paratekstu tłumaczeń biblijnych Wujka, paratekstu niekoniecznie w całości jego autorstwa, otwiera szerokie perspektywy badań. Moga one wydobyć na jaw nie znane dotąd fakty oraz w dużym stopniu pogłębić wiedzę nie tylko o tzw. Biblii Wujka, lecz i o współpracy jezuitów z różnych krajów, o głębokiej wymianie kulturowej, a tym samym o procesach kształtujaccych kulturę Rzeczypospolitej w stopniu niemożliwym do przeszacowania.

Przedstawione zagadnienia - oczywiście jedynie zarysowane - pokazują, że w wypadku tego typu badań konieczna jest kooperacja zespołu pracownic i pracowników naukowych, reprezentujących różne dyscypliny: filologię polska, angielską i łacińską, wielorakie specjalizacje historyczne, również teologię. Tylko wieloaspektowe studia nad tym tematem, prowadzone $\mathrm{z}$ uwzględnieniem kilku uzupełniających się perspektyw, mogą doprowadzić do zadowalających rezultatów.

Abstract

TADEUSZ RUBIK University of Warsaw

DID JAKUB WUJEK KNOW ENGLISH? THE 1593 NEW TESTAMENT AND THE ENGLISH SOURCE OF ITS PARATEXT

A deeply rooted literary conviction is that Jakub Wujek was the author of paratext of his translation of the New Testament (1593), Psalter (1594) and the entire Bible (1599). The latest research points at the problem raised as early as in 1989 by David Frick of dependence of a great part of the New Testament paratext edition (also in fragments which seem to be literal translation) on an English, Catholic source. The matter poses the question if Jakub Wujek knew English or if he took advantage of someone's help. The present paper describes the degree of dependency of the two texts' paratext and analyses the connections between Polish and British Catholics. As based on the prefaces to the editions of Wujek's translation, it proves that no convincing evidence can point at Wujek as at a translator of the New Testament paratext. The author of the paper also analyses the possible research courses and perspectives which result from discerning the problem, and signals the necessity of verification the current state of art. 